\title{
Hubungan tinggi kepala dengan tinggi badan untuk identifikasi forensik
}

\author{
${ }^{1}$ Beatrice Poluan \\ ${ }^{2}$ Djemi Tomuka \\ ${ }^{2}$ Erwin G. Kristanto \\ ${ }^{1}$ Kandidat Skripsi Fakultas Kedokteran Universitas Sam Ratulangi Manado \\ ${ }^{2}$ Bagian Ilmu Forensik dan Medikolegal Fakultas Kedokteran \\ Universitas Sam Ratulangi Manado \\ Email: beatricepoluan12144@yahoo.com
}

\begin{abstract}
Forensic identification is a method to provide assistance for investigators in fulfilling visum et repertum requests and to identify death bodies. Forensic anthropology assists the process of visum et repertum. Forensic anthropology is the application of physical anthropology science inter alia by using anthropometry; certain body parts are measured. Body height is one of the major point in identification and in forensic anthropology, body height is one of the main biological profiles. Head height can be used to determine body height because there is a significant correlation between these two biological profiles. This study aimed to obtain the relationship between head height and body height. This was an analytical study with a cross sectional design. Subjects were students of batch 2012 of Faculty of Medicine, University of Sam Ratulangi Manado, aged 21-22 years. The results showed a positive correlation $r=0.691$ with a probablity value of 0.000 . Conclusion: There was a significant correlation between head height and body height.
\end{abstract}

Keywords: forensic identification, forensic anthropology, anthropometry.

\begin{abstract}
Abstrak: Identifikasi forensik merupakan upaya yang dilakukan dengan tujuan membantu penyidik dalam memenuhi permintaan visum et repertum untuk menentukan identitas seseorang. Antropologi forensik merupakan penerapan ilmu antropologi fisik dengan menggunakan antropometri yaitu salah satu metode pengukuran bagian tubuh. Tinggi badan merupakan salah satu ciri utama untuk proses identifikasi. Dalam antropologi forensik, tinggi badan merupakan salah satu profil biologis utama. Bagian tubuh yang dapat diukur untuk menentukan tinggi badan ialah antara lain tinggi kepala karena terdapat hubungan yang kuat antara keduanya. Tinggi badan dan tinggi kepala berbanding lurus karena setiap terjadi pertambahan tinggi badan, tinggi kepala juga bertambah. Penelitian ini bertujuan untuk mengetahui hubungan antara tinggi kepala dan tinggi badan. Jenis penelitian ini analitik dengan desain potong lintang. Subyek penelitian ialah mahasiswa Fakultas Kedokteran Universitas Sam Ratulangi Manado angkatan 2012 yang berusia 21-22 tahun. Hasil penelitian memperlihatkan terdapat korelasi positif yang signifikan antara tinggi kepala dan tinggi badan dengan nilai koefisien $r=0,691$, dan nilai probabilitas 0,000 . Simpulan: Terdapat hubungan bermakna antara tinggi kepala dan tinggi badan.
\end{abstract}

Kata kunci: identifikasi forensik, antropologi forensik, antropometri

Identifikasi forensik merupakan upaya yang dilakukan dengan tujuan membantu penyidik dalam memenuhi permintaan visum et repertum, untuk menentukan identitas seseorang. Sebagai alat bukti yang sah, keterangan ahli kedokteran forensik dalam perkara pidana menyangkut tubuh, kesehatan dan nyawa manusia dituangkan 
dalam visum et repertum. ${ }^{1}$

Antropologi forensik dapat membantu kepentingan visum et repertum. Antropologi forensik adalah penerapan ilmu antropologi fisik. Dalam kasus pidana korban tetap berada di tahap lanjutan dekomposisi sehingga antropologis forensik dapat membantu dalam identifikasi jenazah yang dimutilasi. ${ }^{2}$

Metode yang digunakan dalam antropologi forensik ialah antropometri. Antropometri merupakan salah satu metode dengan cara mengukur bagian tubuh. Pengukuran antoprometri berdasarkan tinggi badan, panjang dan lebar kepala, sidik jari, bentuk hidung, telinga, dagu, warna kulit, warna rambut, tanda pada tubuh, serta DNA. Tinggi badan merupakan salah satu ciri utama untuk proses identifikasi. Dalam antropologi forensik, tinggi badan merupakan salah satu profil biologis utama. ${ }^{3}$

Metode lain yang dapat digunakan ialah mengukur panjang segmen tertentu dan dimasukkan dalam rumus tinggi badan sesuai segmen yang diukur, misalnya panjang tulang tertentu. ${ }^{4}$

Tinggi badan merupakan salah satu ciri utama untuk proses identifikasi. Dalam antropologi forensik, tinggi badan merupakan salah satu profil biologis utama. Salah satu bagian tubuh yang dapat diukur untuk menentukan tinggi badan ialah tinggi kepala karena terdapat hubungan yang kuat antara keduanya. Tinggi badan dan tinggi kepala berbanding lurus karena setiap terjadi pertambahan tinggi badan, tinggi kepala juga bertambah.

\section{METODE PENELITIAN}

Jenis penelitian ini analitik dengan desain potong lintang. Penelitian ini bertujuan untuk mendapatkan hubungan antara tinggi badan dan tinggi kepala. Penelitian ini dikuantifikasi dengan analisis. Penelitian ini dilakukan di Manado pada bulan Oktober sampai dengan Desember 2015. Populasi ialah mahasiswa Faktultas Kedokteran Universitas Sam Ratulangi Manado angkatan 2012 yang berusia 21 - 22 tahun.

\section{HASIL PENELITIAN DAN BAHASAN}

Tabel 1 memperlihatkan distribusi frekuensi subyek dimana yang berusia 21 tahun berjumlah 38 orang dan yang 22 tahun berjumlah 1 orang.

Tabel 1. Distribusi subyek berdasarkan usia

\begin{tabular}{ccccc}
\hline Valid & Frequency & $\%$ & $\begin{array}{c}\text { Valid } \\
\text { Percent }\end{array}$ & $\begin{array}{c}\text { Cumulative } \\
\text { Percent }\end{array}$ \\
\hline 21 & 38 & 97,4 & 97,4 & 97,4 \\
22 & 1 & 2,6 & 2,6 & 100 \\
Total & 39 & 100 & 100 & \\
\hline
\end{tabular}

Tabel 2 memperlihatkan distribusi frekuensi subyek menurut jenis kelamin. Subyek dengan jenis kelamin laki-laki sebanyak 25 orang dan yang perempuan 14 orang.

Tabel 2. Distribusi subyek berdasarkan jenis kelamin

\begin{tabular}{c|c|c|c|c}
\hline Valid & Frequency & Percent & $\begin{array}{l}\text { Valid } \\
\text { Percent }\end{array}$ & $\begin{array}{l}\text { Cumulative } \\
\text { Percent }\end{array}$ \\
\hline L & 25 & 64,1 & 64,1 & 64,1 \\
P & 14 & 35,9 & 35,9 & 100 \\
Total & 39 & 100 & 100 & \\
\hline
\end{tabular}

$\mathrm{L}=$ Laki-laki

$\mathrm{P}=$ Perempuan

Tabel 3 menunjukkan minimum usia pada subyek laki-laki dan perempuan 21 tahun dan maksimal usia 22 tahun. Rerata usia ialah 21,02 dengan standar deviasi 0,160 .

Tabel 3. Minimum, maksimum, rerata, dan standar deviasi dari usia subyek

\begin{tabular}{cccccc}
\hline & $\mathrm{N}$ & Min & Maks & Rerata & SD \\
\hline Usia & 39 & 21 & 22 & 21,02 &, 160 \\
$\mathrm{~N}$ & 39 & & & & \\
\hline
\end{tabular}

$\mathrm{N} \quad=$ Jumlah subyek penelitian

Min = Nilai terendah dalam variabel

Maks = Nilai tertinggi dalam variabel

$\mathrm{SD} \quad=$ Standar Deviasi

Tabel 4 menunjukkan bahwa rerata tinggi badan pada subyek laki-laki dan perempuan ialah 161,3 cm dengan variasi tinggi badan minimum 134,1 cm dan tinggi 
badan maksimum 178,2 cm. Rerata tinggi kepala pada subyek laki-laki dan perempuan ialah 21,92 cm dengan variasi tinggi kepala minimum 18,9 cm dan tinggi kepala maksimum $26 \mathrm{~cm}$.

Tabel 4. Nilai rerata, minimum, maksimum dan standar deviasi untuk pengukuran tinggi badan dan tinggi kepala subyek

\begin{tabular}{llllll}
\hline & $\mathrm{N}$ & Min & Max & Rerata & SD \\
\cline { 2 - 6 } TB & 39 & 134,1 & 178,2 & 161,3 & 161,3 \\
TK & 39 & 18.9 & 26 & 21,92 & 1,47 \\
N & 39 & & & & \\
\hline
\end{tabular}

$\begin{array}{ll}\text { TB } & =\text { Tinggi badan } \\ \text { TK } & =\text { Tinggi kepala } \\ \mathrm{N} & =\text { Jumlah subyek penelitian } \\ \text { Min } & =\text { Nilai terendah dalam variabel } \\ \text { Maks } & =\text { Nilai tertinggi dalam variabel } \\ \text { SD } & =\text { Standar Deviasi }\end{array}$

Tabel 5 menunjukkan hasil uji normalitas pengukuran tinggi badan dan tinggi kepala dengan uji Shapiro-Wilk. Nilai signifikan tinggi badan 0,274 dan nilai signifikan tinggi kepala 0,235 yang berarti berdistribusi normal dengan nilai probabilitas $>0,05$.

Tabel 5. Hasil uji normalitas pengukuran tinggi badan dan tiggi kepala dengan perhitungan Shapiro-Wilk.

\begin{tabular}{cccc}
\hline & \multicolumn{3}{c}{ Shapiro-Wilk } \\
\cline { 2 - 4 } & Statistic & df & Sig. \\
\hline TB &, 966 & 39 &, 274 \\
TK &, 964 & 39 &, 235 \\
\hline
\end{tabular}

TB $=$ Tinggi badan

TK = Tinggi kepala

Tabel 6 menunjukkan hasil korelasi antara tinggi kepala dan tinggi badan dengan nilai koefisien $r=0,691$ yang menandakan hubungan yang kuat antara kedua variabel. Dari hasil korelasi tersebut didapatkan juga nilai probabilitas (signifikan) $=0,000$ yang berarti terdapat hubungan bermakna antara kedua variabel tersebut.

Penelitian ini menggunakan rumus besaran sampel Slovin dan didapatkan besaran subyek sebanyak 39. Data dianalisis menggunakan statistik deskriptif untuk mendapatkan rerata dan standar deviasi, serta dilakukan uji korelasi Pearson (Product Moment Analysis).

Tabel 6. Hasil korelasi antara tinggi kepala dan tinggi badan

\begin{tabular}{lcc}
\hline & TK & TB \\
\hline TK Pearson Correlation & 1 &, $691^{* *}$ \\
Sig. (2-tailed) & &, 000 \\
$\mathrm{~N}$ & 39 & 39 \\
\hline TB Pearson Correlation &, $691^{* *}$ & 1 \\
Sig. (2-tailed) &, 000 & \\
$\mathrm{~N}$ & 39 & 39 \\
\hline TB = Tinggi badan & & \\
TK $=$ Tinggi kepala & &
\end{tabular}

Sebelum melakukan analisis korelasi, dilakukan uji kenormalan data dengan menggunakan One Sample Kolmogorov Smirnov Test. Pada penelitian ini, variabel yang dikorelasikan menggunakan uji korelasi Pearson yakni antara variabel tinggi badan (basis-vertex) dengan tinggi kepala (vertex-region).

\section{SIMPULAN}

Dari hasil penelitian dan bahsan dapat disimpulkan bahwa terdapat korelasi positif yang signifikan antara tinggi kepala dengan tinggi badan dengan hasil perbandingan antara tinggi kepala dan tinggi badan 1 : 7 .

\section{DAFTAR PUSTAKA}

1. Mun'im Idries, Abdul dan Legowo Tjiptomartono, Agung. Penerapapn Ilmu Kedokteran Forensik dalam Proses Penyidikan. Jakarta: Sagung Seto, 2008; p. 88.

2. Forensic Anthropology. Available from: Id.termwiki.com/id/forensic_anthopolo gy

3. Tinggi badan berdasarkan tulang tibia, humerus, ulna dan radius pada laki-laki dewasa muda. Available from: http://repository.maranatha.edu/8764/3/0 810216_Chapter1.pdf.

4. Idrianti E. Antropologi Forensik: Identifikasi Rangka Manusia, Aplikasi Antropologi Biologis dalam Konteks Hukum. Yogyakarta: Gadjah Mada Universitas Press, 2004. 